\title{
Seasonal Colonization of Arbuscular Mycorrhiza Fungi in the Roots of Camellia sinensis (Tea) in Different Tea Gardens of India
}

\author{
Chitra Sharma, ${ }^{1}$ Rajan K. Gupta, ${ }^{1}$ Rakesh K. Pathak, ${ }^{2}$ and Kaushal K. Choudhary ${ }^{3}$ \\ ${ }^{1}$ Department of Botany, Government Post Graduate Autonomous College, Rishikesh 249201, Uttarakhand, India \\ ${ }^{2}$ Department of Botany, D.A.V. (P.G.) College, Dehradun 248001, Uttarakhand, India \\ ${ }^{3}$ Department of Botany, Dr. Jagannath Mishra College, Muzaffarpur 842001, Bihar, India
}

Correspondence should be addressed to Kaushal K. Choudhary; kkc1970@gmail.com

Received 18 October 2013; Accepted 3 December 2013

Academic Editors: I. Bisht and A. Chistoserdov

Copyright (C) 2013 Chitra Sharma et al. This is an open access article distributed under the Creative Commons Attribution License, which permits unrestricted use, distribution, and reproduction in any medium, provided the original work is properly cited.

Study describes Arbuscular Mycorrhiza (AM) fungi colonization within the roots of cultivated tea plants (Camellia sinensis) at four sites, that is, Goodrich, Archadia, IIP, and Vasant Vihar of Doon Valley, Dehradun, India, from April, 2008, to March, 2009. Microscopic study of sterilized and stained root segments showed presence of four species namely Glomus fasciculatum, G. mosseae, Gigaspora margarita, and Acaulospora scrobiculata belonging to three genera of mycorrhizal fungi. Maximum AM colonization was observed during April-September and minimum was observed for December-January months of the year. Comparative study of AM fungi colonization at four sites during rainy season showed maximum colonization (100\%) at Archadia site having soil with high organic matter, less acidity, and low phosphorus (P) whereas minimum (64.59\%) at IIP with low organic matter, more acidity, and high $\mathrm{P}$ content. However, no variation in nitrogen content was observed at all four sites. Study suggested a positive relation of percentage root colonization with soil organic matter and negative relation with acidity and $\mathrm{P}$ content of soil. Study concludes that the percentage AM colonization is the function of seasonal variation in physicochemical properties of soil and presence of AM inoculums in the soil at a particular time.

\section{Introduction}

Increasing concern over industry based development and related risk of environment, energy, and food security has stimulated scientists to develop and design biosystems as alternate or supplementary sources of biofertilizer for sustainable practices, particularly for agriculture and remediation of degraded lands. Mycorrhizas - a symbiotic association between the fungi and the roots of higher plants [1] are receiving more attention worldwide for their ability to enhance the uptake and absorption of relatively immobile nutrients and minerals of plants due to comparatively large surface area of mycelium : root ratio [2]. Mycorrhizal associations occur naturally with more than $95 \%$ of terrestrial plants, of which $65 \%$ belong to Arbuscular Mycorrhiza (AM) fungi $[3,4]$. Inoculation of AM fungi with different plants showed increased uptake of nitrogen $(\mathrm{N})$ by plants [5], promotion of plant growth [6], exchange of water and mineral with soil [7], resistance to stress and drought and in some cases to soil pathogens $[8,9]$, and metals toxicity resistance to plants [10]. Establishment of mycorrhizal associations supports up to $80 \%$ of $\mathrm{N}$ and $90 \% \mathrm{P}$ requirements of plants [11].

Camellia sinensis is widely used for the cheapest aromatic beverages in the world [12]. Consumption of C. sinensis has profound effects on health as it contains more than 700 chemicals such as flavanoids, amino acids, vitamins (C, E, and $\mathrm{K})$, caffeine, and polysaccharides. Beneficial role of C. sinensis in normalizing blood pressure, lipid depression activity, prevention of coronary heart diseases, and diabetes by reducing the blood glucose activity as well as the presence of catechins (an antioxidant) has elevated this plant at industry level and has profound effect on economic growth of a country. However, application of chemical fertilizers for quantitative production is adversely affecting the quality of tea. Therefore, 


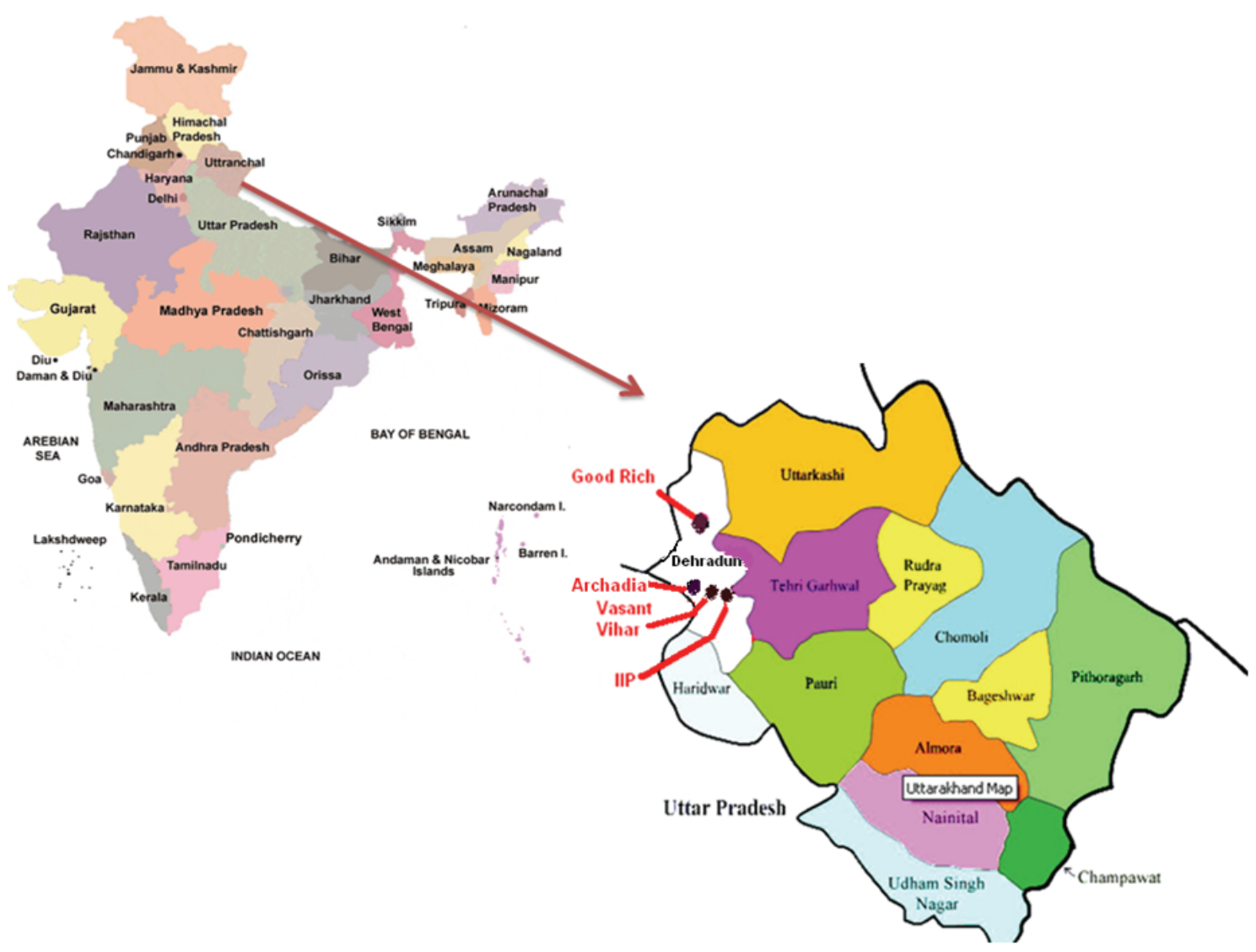

FIGURE 1: Location of four study sites on geographical map.

AM fungi colonizing the tea plants are getting more attention for their ability to support the growth. Although, percentage root colonization of AM fungi with C. sinensis roots [13, 14] and with other plants like Pine-Oak forests [15] in the Himalayan region has been variously studied, detailed study on percentage root colonization with respect to seasonal change that might support the annual nutrient management is scarce. Considering the significant nutrient contribution of AM fungi and ultimate requirement of sustainable nutrient management, present study is proposed to enumerate the colonization of AM fungi in the roots of $C$. sinensis during different months for a year.

\section{Materials and Methods}

2.1. Study Area. The study was conducted on 4 th year of tea plantation at four selected sites, namely, Goodrich, Archadia, IIP and Vasant Vihar located at the foot hills of the Himalayas at Doon Valley, Dehradun, India, from April, 2008, to March, 2009. Geographical location of four different sites has been presented in Figure 1. Dehradun is located at the latitude of $30^{\circ} 19^{\prime} \mathrm{N}$ and longitude of $78^{\circ} 04^{\prime} \mathrm{E}$ and is situated between the Himalayas in the north and Shivalik range in the south. Climate of Dehradun is generally temperate and varies from hot in summers to severely cold in winter. Average annual temperature ranges from 5 to $35^{\circ} \mathrm{C}$ and average annual rainfall is $2073.3 \mathrm{~mm}$. Study was conducted in the area of $100 \mathrm{~m} \times 70 \mathrm{~m}$ for each selected site. The distance between Goodrich (north end of the study site) and IIP (south end of the study site) sites is $73 \mathrm{Km}$. Archadia and Vasant Vihar are located at a distance of 48 and $66 \mathrm{Km}$ from Goodrich site, respectively.

2.2. Root Sampling. Percentage root colonization of AM fungi was documented with root samples collected from the "root zones" of the Camellia sinensis plants at the depth of 15 to $20 \mathrm{~cm}$ below the soil surface. Root sampling was done randomly between 8 and 10 am in middle of every month for one year. Eighty root samples were collected in conical flasks for each selected site separately and brought to the laboratory. Study of the root samples for AM colonization was performed on the very next day of the collection. Roots were kept in running tap water for half an hour and washed thrice with sterile double distilled water to avoid the presence of other microbes or AM fungi adsorbed to the root surface.

2.3. Research Methods. AM fungi colonization with the root samples was assessed following the slide method of Giovannetti and Mosse [16]. Root samples were cut into pieces of $1 \mathrm{~cm}$ length and stained with $0.05 \%$ cotton blue in lactophenol. Excess stain was removed with clear lactophenol. Root segments $(1 \mathrm{~cm}$ long) were selected randomly from stained samples and mounted on microscopic slides in groups of 10 pieces. Presence and absence of infection were recorded microscopically in each of the 80 root segments for each site 
TABLE 1: Percentage root colonization of AM fungi in the roots of tea plants at Archadia, Goodrich, IIP, and Vasant Vihar sites during different months of the year.

\begin{tabular}{ccccccc}
\hline & Months & & \multicolumn{2}{c}{ Sites } & Level of & CD \\
significance
\end{tabular}

$* * *$ : significant at 0.001 .

separately for different months of the year and percentage root colonization was calculated. Mycorrhizal fungi were studied for their cellular organization, color, shape and size, wall structure, and position of the vesicles and arbuscules and identified with the help of the literature [17-19]. Micrograph of AM fungi was assessed under a stereomicroscope (Olympus SZ H10 research microscope).

2.4. Analysis. $\mathrm{pH}$ of the soil sample was determined in $1: 5$ suspension of soil: deionised water electrometrically using glass electrode $\mathrm{pH}$ meter 335 (Systronics India Limited). Organic carbon was determined by using Walkley and Black's rapid titration method [20] and total nitrogen (N) and phosphorus $(\mathrm{P})$ were determined using the method of Jackson [21].

2.5. Statistical Analysis. Data presented in the tables are the mean values of the analysis. Data produced for different parameters were subjected to multifactor analysis using SPSS software version 10.0 .

\section{Results}

The study describes the differences in monthly colonization of AM fungi in the $C$. sinensis roots round the year at four different sites. Different stages of AM fungi inside root of $C$. sinensis have also been studied and presented in Figure 2.

Extensive study carried out to enumerate the AM fungi colonization in the roots of $C$. sinensis showed differences in percentage root colonization (PRC) during different months of the year at four selected sites (Table 1). Study showed maximum AM fungi colonization at Archadia (100\%) followed by Vasant Vihar (92.69\%), Goodrich (83.64\%), and IIP (64.59\%) sites (Table 1). Detailed analysis of percentage root colonization during different months of the year showed that the PRC for all four sites was above/around the annual mean from April to September (hot and humid summer) and
TABLE 2: Statistical analysis of percentage root colonization of AM fungi in the roots of $C$. sinensis at four sites.

\begin{tabular}{lcccc}
\hline $\begin{array}{l}\text { Statistical } \\
\text { parameters }\end{array}$ & Archadia & Goodrich & IIP & Vasant Vihar \\
\hline Mean & 62.29 & 55.68 & 33.10 & 63.36 \\
Range & 67.50 & 52.48 & 47.96 & 61.49 \\
$\begin{array}{l}\text { Coefficient of } \\
\text { range }\end{array}$ & 0.51 & 0.46 & 0.59 & 0.50 \\
SD & 23.65 & 19.09 & 13.78 & 23.79 \\
\hline
\end{tabular}

below the annual mean from October to March (cold winter). Annual mean was 62.29, 55.68, 33.10, and 63.36 for Archadia, Goodrich, IIP, and Vasant Vihar, respectively (Table 2). AM fungi colonization started to decrease with the onset of cold winter, that is, from the month of October, and reached to lowest during the coldest months of December-January and started to increase with onset of rainy summer. Differential colonization of tea plants with AM fungi during different months of the year indicated the possible role of climatic and edaphic factors.

$\mathrm{pH}$, organic matter, and nitrogen and phosphorus content of soil for four different sites are presented in Table 3. Relation between $\mathrm{pH}$ and organic matter of the soil and AM colonization was positive, that is, increase in $\mathrm{pH}$ and organic matter was directly related to increase in PRC. However, soil phosphorus has negative relation with percentage root colonization. IIP site with higher $\mathrm{P}$ content has low PRC whereas Archadia site with low soil P has high PRC. The P content of different sites might be presented as Archadia < Vasant Vihar < Goodrich < IIP whereas PRC as Archadia $>$ Vasant Vihar $>$ Goodrich $>$ IIP. There were no significant differences in nitrogen status of the soil at different sites.

Statistical analysis of the AM colonization for selected sites around the year showed that AM colonization has great affinity with season and significantly different for all sites 


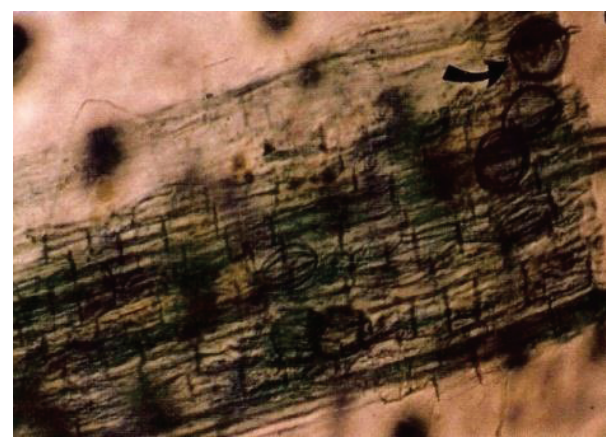

(a) Hyphae and vesicle in C. sinensis root cortex

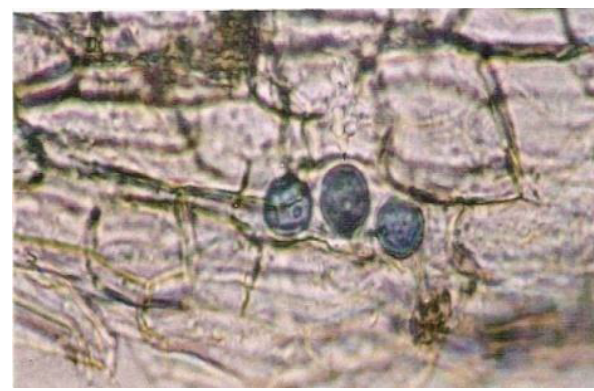

(c) Vesicle in the root of C. sinensis

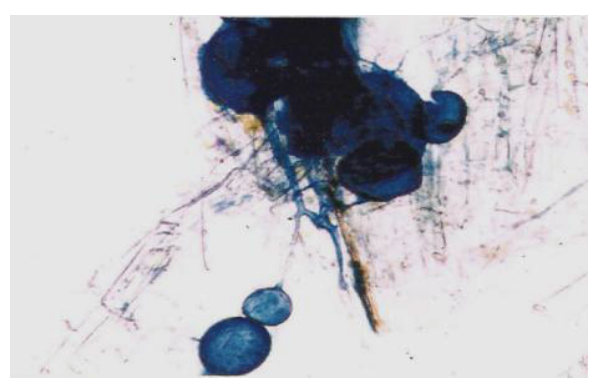

(e) Liberating spores and vesicles outside the root cortex

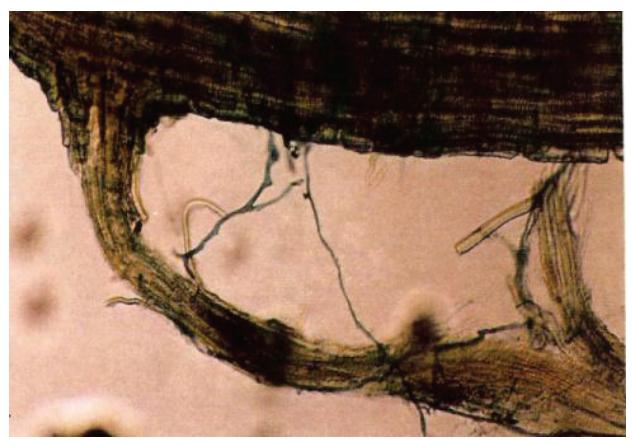

(b) AM hyphae penetrating C. sinensis root

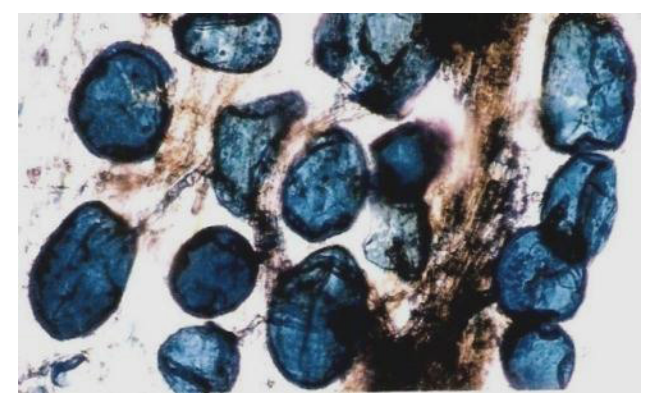

(d) Hyphae swell apically to form vesicles

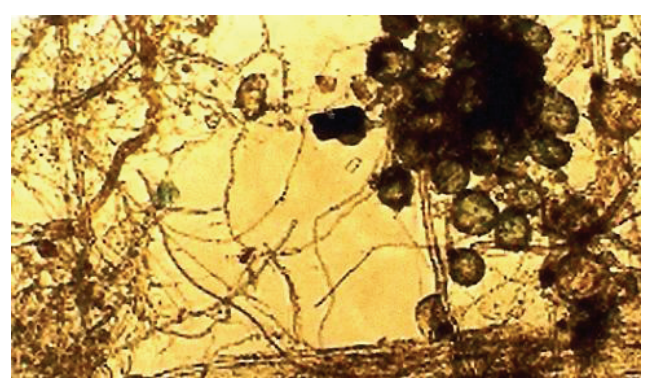

(f) Spore and vesicle in C. sinensis root

FIGURE 2: Different stages of AM colonization in the roots of C. sinensis.

(Table 1). Study gets support from the coefficient of range predicted in Table 2. In spite of significant differences in percentage colonization at four sites ranging from $100 \%$ (maximum) at Archadia site to $16.6 \%$ (minimum) at IIP site, annual coefficient of range was between 0.46 and 0.59 . The study supports that the AM colonization with roots of $C$. sinensis is correlated to seasonal variation in climatic factors and also to AM inocula present at a given time. It was observed that minimum colonization at IIP site in the stress condition of light and temperature during DecemberJanuary followed the similar trend of minimum colonization during favourable condition of May-June compared to that of other sites. However, the more is the colonization at Archadia site during December-January, the maximum was the colonization during May-June.

Microscopic study showed the presence of four species of AM fungi belonging to three genera of class Glomeromycota and were represented by Glomus fasciculatum, G. mosseae (family Glomaceae), Gigaspora margarita, and Acaulospora scribiculata (family Acaulosporeacae). Hyphae and vesicles were the most common structures observed for root segments under microscope (Figure 2(a)). However, hyphae were predominantly present for all selected sites (Figure 2(b)). The root samples of $C$. sinensis showed typical wider and aseptate hyphae growing inter- and intracellularly through the cortex and penetrating to the inner cortex (Figures 2(b) and 2(c)). Vesicles were mostly globose to subglobose or ellipsoidal in shape inside the roots of $C$. sinensis (Figure 2(d)). The arbuscules were observed in cells of the inner cortex. Vesicles with group of spores were also seen in the roots of C. sinensis (Figures 2(e) and 2(f)). Further investigation in terms of species abundance showed predominance of Glomus sp. followed by Acaulospora scribiculata and Gigaspora margarita.

\section{Discussion}

AM fungi have been variously studied for their contribution in degraded land as well as their potential application in agriculturally cultivated plants for enhanced production [22]. 
TABLE 3: Annual averages of $\mathrm{pH}$, organic matter, and nitrogen and phosphorus content at four sites.

\begin{tabular}{lcccc}
\hline Sites & $\mathrm{pH}$ & Organic matter (\%) & Nitrogen (\%) & Phosphorus (ppm) \\
\hline Archadia & 5.7 & 2.20 & $0.21 \pm 0.03$ & $12.60 \pm 0.44$ \\
Goodrich & 5.1 & 1.35 & $0.17 \pm 0.02$ & $25.64 \pm 0.09$ \\
IIP & 4.8 & 1.20 & $0.18 \pm 0.01$ & $28.17 \pm 0.29$ \\
Vasant Vihar & 5.4 & 1.55 & $0.18 \pm 0.02$ & $22.55 \pm 0.02$ \\
\hline
\end{tabular}

The present study describes the colonization of C. sinensis roots with AM fungi round the year on monthly basis. Maximum root colonization during hot and humid summer (rainy season, i.e., during April-September) and decrease in colonization with the start of cold winter during the months of October-March were in accordance with the study reported by Chandra and Jamaluddin [23]. They also observed the similar result of maximum AM fungi colonization during rainy season in C. sinensis root. Gould et al. [24] also observed the maximum root colonization and spore population density during June and minimum during October-November on reclaimed sites of Archadia. Similar observation of negative relation between $\mathrm{P}$ content and AM colonization has been reported by Nagahashi et al. [25]. They reported that increase in $\mathrm{P}$ content significantly inhibited the number of branches and total hyphae length. Negative effect of $\mathrm{P}$ on AM colonization suggests that plant itself is capable of absorbing sufficient amount of $\mathrm{P}$ required for growth and development. Increase in P brings about anatomical and physiological changes in the roots that inhibit or limit the vigorous intraradical spread of AM fungi [25-27]. Positive effect of $\mathrm{pH}$ on AM colonization might be compared to the report by Medeiros et al. [28]. They reported the significant increase in root colonization of Sorghum plant with AM fungi with increasing $\mathrm{pH}$. Positive relation of percentage root colonization of AM fungi with organic matter observed in this study was in accordance with Vaidya et al. [29] who reported increased AM population with increase in organic matter. Study reflects that the site Archadia having low phosphorus has high organic matter and high percentage of AM root colonization. In contrast, site IIP with high P content has low organic matter and low percentage of AM root colonization. It might be explained by the fact that high $\mathrm{P}$ content in the soil in the root limits the supply of organic carbon to the AM fungus of the colonized root thereby causing reduced extension of hyphae and development of spores [30].

Further investigation of differences in percentage colonization at different sites and differences in range might be attributed to the initial inocula of the AM fungi in the field under natural condition. It is apparent from the study that IIP site with less AM fungi inocula (lower PRC) has minimum percentage of root colonization during favorable condition of May-June; whereas Archadia site with more AM fungi inocula (higher PRC) has maximum percentage of root colonization during favorable condition of May-June (compared to all four sites). Moreover, dominance of Glomus sp. followed by Acaaulospora and Gigaspora sp. is comparable to Zhao et al. [22]. They reported similar observations of dominance of Glomus sp. and Acaulospora sp. in the tropical rainforests of Xishuangbanna in southwestern China. The differences in percentage root colonization and species abundance might be attributed to change in climatic conditions round the year. Varied diversity of AM fungi associated with different plants is already in the literature [31, 32]. In addition, seasonality, physiochemical properties of soil, host dependence, age of the host plants, and dormancy might play significant role in AM establishment and diversity [33]. The present study will certainly help in maintaining the nutrient status of the soil during lower rate of AM colonization by introducing comparatively high nutrient into the soil to maintain the growth of tea plants during stress period of cold.

\section{Conclusion}

The present study of percentage root colonization at different tea planted sites on monthly basis might contribute significantly in the future management of nutrient status of soil under field condition for better application of AM fungi for better yield. Establishment of AM fungi in field condition might support the proliferation of some important microbes that actively contribute in nitrogen and other nutrient cycling. The research output of present study concludes that maximum AM fungi colonization during rainy season is probably due to physico-chemical properties of soils and surroundings.

\section{Acknowledgments}

The authors wish to thank the owner of Goodrich Tea Estate (Vikasnagar) Mahant Shri Devendra Dass ji Maharaj (Darbar Shri Guru Ram Rai Ji Maharaj), Dehradun, for giving place to set up tea nursery, Mr. Digvijay Singh Rawat, the Manager of Tea Estate, for the tea plants given by them, and the Department of Botany, Govt. P.G. College, Rishikesh, for laboratory facilities. The authors are thankful to the University Grants Commission, New Delhi, and the Uttarakhand Council for Science and Technology, Dehradun, for financial assistance.

\section{References}

[1] A. B. Frank, "Über die auf Wurzelsymbiose beruhende Ernährung gewisser Bäume durch unterirdische Pilze," Ber Deutsch Bot Gesells, vol. 3, pp. 128-145, 1985.

[2] E. Smith and D. J. Read, Mycorrhizal Symbiosis, Academic Press, London, UK, 3rd edition, 2008.

[3] B. Wang and Y.-L. Qiu, "Phylogenetic distribution and evolution of mycorrhizas in land plants," Mycorrhiza, vol. 16, no. 5, pp. 299-363, 2006.

[4] M. C. Brundrett, "Mycorrhizal associations and other means of nutrition of vascular plants: understanding the global diversity 
of host plants by resolving conflicting information and developing reliable means of diagnosis," Plant and Soil, vol. 320, no. 1-2, pp. 37-77, 2009.

[5] F. Ganryl, H. G. Diem, J. Wey, and Y. R. Dommergues, "Inoculation with Glomus mosseae improves $\mathrm{N}_{2}$ fixation by field-grown soybeans," Biology and Fertility of Soils, vol. 1, no. 1, pp. 15-23, 1985.

[6] T. Muthukumar and K. Udaiyan, "Growth of nursery-grown bamboo inoculated with arbuscular mycorrhizal fungi and plant growth promoting rhizobacteria in two tropical soil types with and without fertilizer application," New Forests, vol. 31, no. 3, pp. 469-485, 2006.

[7] R. N. Ames, C. P. P. Reid, K. K. Porter, and C. Cambardella, "Hyphal uptake and transport of nitrogen from two ${ }^{15} \mathrm{~N}$ leveled source by Glomus mosseae arbuscular mycorrhizal fungus," New Phytologist, vol. 95, no. 3, pp. 381-396, 1989.

[8] R. M. Augé, "Water relations, drought and vesicular-arbuscular mycorrhizal symbiosis," Mycorrhiza, vol. 11, no. 1, pp. 3-42, 2001.

[9] B. A. Sikes, K. Cottenie, and J. N. Klironomos, "Plant and fungal identity determines pathogen protection of plant roots by arbuscular mycorrhizas," Journal of Ecology, vol. 97, no. 6, pp. 1274-1280, 2009.

[10] A. Liu, C. Hamel, R. I. Hamilton, B. L. Ma, and D. L. Smith, "Acquisition of $\mathrm{Cu}, \mathrm{Zn}, \mathrm{Mn}$ and $\mathrm{Fe}$ by mycorrhizal maize (Zea mays L.) grown in soil at different $\mathrm{P}$ and micronutrient levels," Mycorrhiza, vol. 9, no. 6, pp. 331-336, 2000.

[11] M. G. A. van der Heijden, R. D. Bardgett, and N. M. van Straalen, "The unseen majority: soil microbes as drivers of plant diversity and productivity in terrestrial ecosystems," Ecology Letters, vol. 11, no. 3, pp. 296-310, 2008.

[12] K. K. G. Menon, “The Camellia sinensis industry in India, how to redesign a native," in Camellia sinensis Culture Processing and Marketing, M. J. Mulky and V. S. Sharma, Eds., pp. 3-10, Oxford and IBH Publishing Co. PVT. Ltd., New Delhi, India, 2002.

[13] S. K. Rajan, B. J. D. Reddy, and D. J. Bagyaraj, "Screening of arbuscular mycorrhizal fungi for their symbiotic efficiency with Tectona grandis," Forest Ecology and Management, vol. 126, no. 2, pp. 91-95, 2000.

[14] R. K. Gupta and C. Sharma, "Diversity of arbuscular mycorrhizal fungi in Camellia sinensis in Uttarakhand state, India," African Journal of Biotechnology, vol. 9, no. 33, pp. 5313-5319, 2010.

[15] S. Chaturvedi, V. Tewari, S. Sharma et al., "Diversity of arbuscular mycorrhizal fungi in Oak-Pine forests and agricultural land prevalent in the Kumaon Himalayan Hills, Uttarakhand, India," British Microbiology Research Journal, vol. 2, no. 2, pp. 82-96, 2012.

[16] M. Giovannetti and B. Mosse, "An evaluation of technologies for measuring vesicular arbuscular mycorrhizal infection in roots," New Phytologist, vol. 84, no. 3, pp. 489-500, 1980.

[17] I. R. Hall, "Taxonomy of VA mycorrhizal fungi," in VA Mycorrhiza, C. L. Powell and D. J. Bagyaraj, Eds., pp. 57-94, CRC Press, Boca Raton, Fla, USA, 1984.

[18] N. C. Schenck and Y. Perez, Manual for the Identification of VA Mycorrhizal Fungi, Synergistic Publications, Gainesville, Fla, USA, 1990.

[19] J. B. Morton and G. L. Benny, "Revised classification of Arbuscular mycorrhizal fungi (Zygomycetes): a new order, Glomales, two new suborders, Glomineae and Gigasporineae, and two new families, Acaulosporaceae and Gigasporaceae, with an emendation of Glomaceae," Mycotaxon, vol. 37, no. 1, pp. 471491, 1990.
[20] A. Walkley and I. A. Black, "An examination of the Degtiareff method for determining soil organic matter and proposed modification of the chromic acid titration method," Soil Science, vol. 37, pp. 29-38, 1934.

[21] M. L. Jackson, Soil Chemical Analysis, Prentice Hall, Englewood Cliffs, NJ, USA, 1958.

[22] Z. W. Zhao, G. H. Wang, and L. Yang, "Biodiversity of arbuscular mycorrhizal fungi in a tropical rainforest of Xishuangbanna, southwest China," Fungal Diversity, vol. 13, pp. 233-242, 2003.

[23] K. K. Chandra and A. Jamaluddin, "Seasonal variation of VAM fungi in tree species planted in coalmine overbunden of Kusmunda (MP)," Journal of Tropical Forest, vol. 14, no. 2, pp. 118-123, 1998.

[24] A. B. Gould, J. W. Hendrix, and R. S. Ferriss, "Relationship of mycorrhizal activity to time following reclamation of surface mine land in western Kentucky. I. Propagule and spore population densities," Canadian Journal of Botany, vol. 74, no. 2, pp. 247-261, 1996.

[25] G. Nagahashi, D. D. Douds Jr., and G. D. Abney, "Phosphorus amendment inhibits hyphal branching of the VAM fungus Gigaspora margarita directly and indirectly through its effect on root exudation," Mycorrhiza, vol. 6, no. 5, pp. 403-408, 1996.

[26] F. Amijee, P. B. Tinker, and D. P. Stribley, "The development of endomycorrhizal root systems. VII. A detailed study of effects of soil phosphorus on colonization," New Phytologist, vol. 111, no. 3, pp. 435-446, 1989.

[27] J. A. Menge, D. Sterile, D. J. Bagyaraj, E. L. V. Johnson, and R. T. Leonard, "Phosphorus concentrations in plants responsible for inhibition of mycorrhizal infection," New Phytologist, vol. 80, no. 3, pp. 575-578, 1978.

[28] C. A. B. Medeiros, R. B. Clark, and J. R. Ellis, "Growth and nutrient uptake of sorghum cultivated with vesicular-arbuscular mycorrhiza isolates at varying pH," Mycorrhiza, vol. 4, no. 5, pp. 185-192, 1994.

[29] G. S. Vaidya, K. Shrestha, B. R. Khadge, N. C. Johnson, and H. Wallander, "Study of biodiversity of arbuscular mycorrhizal Fungi in addition with different organic matter in different seasons of Kavre district (central Nepal)," Scientific World, vol. 5, no. 5, pp. 76-80, 2007.

[30] D. D. Douds, "Relationship between hyphal and arbuscular colonization and sporulation in a mycorrhiza of Paspalum notatum Flugge," New Phytologist, vol. 126, no. 2, pp. 233-237, 1994.

[31] F. Y. Wang and S. Y. Shi, "Biodiversity of Arbuscular mycorrhizal fungi in China: a review," Advances in Environmental Biology, vol. 2, no. 1, pp. 31-39, 2008.

[32] S. Gaur and P. Kaushik, "Biodiversity of vesicular arbuscular mycorrhiza associated with Catharanthus roseus, Ocimum spp. and Asparagus racemosus in Uttarakhand state of Indian Central Himalaya," International Journal of Botany, vol. 7, no. 1, pp. 3141, 2011.

[33] J. N. Gemma and R. E. Koske, "Seasonal variation in spore abundance and dormancy of Gigaspora gigantea in mycorrhizal inoculum potential of a dune soil," Mycologia, vol. 80, no. 2, pp. 211-216, 1988. 

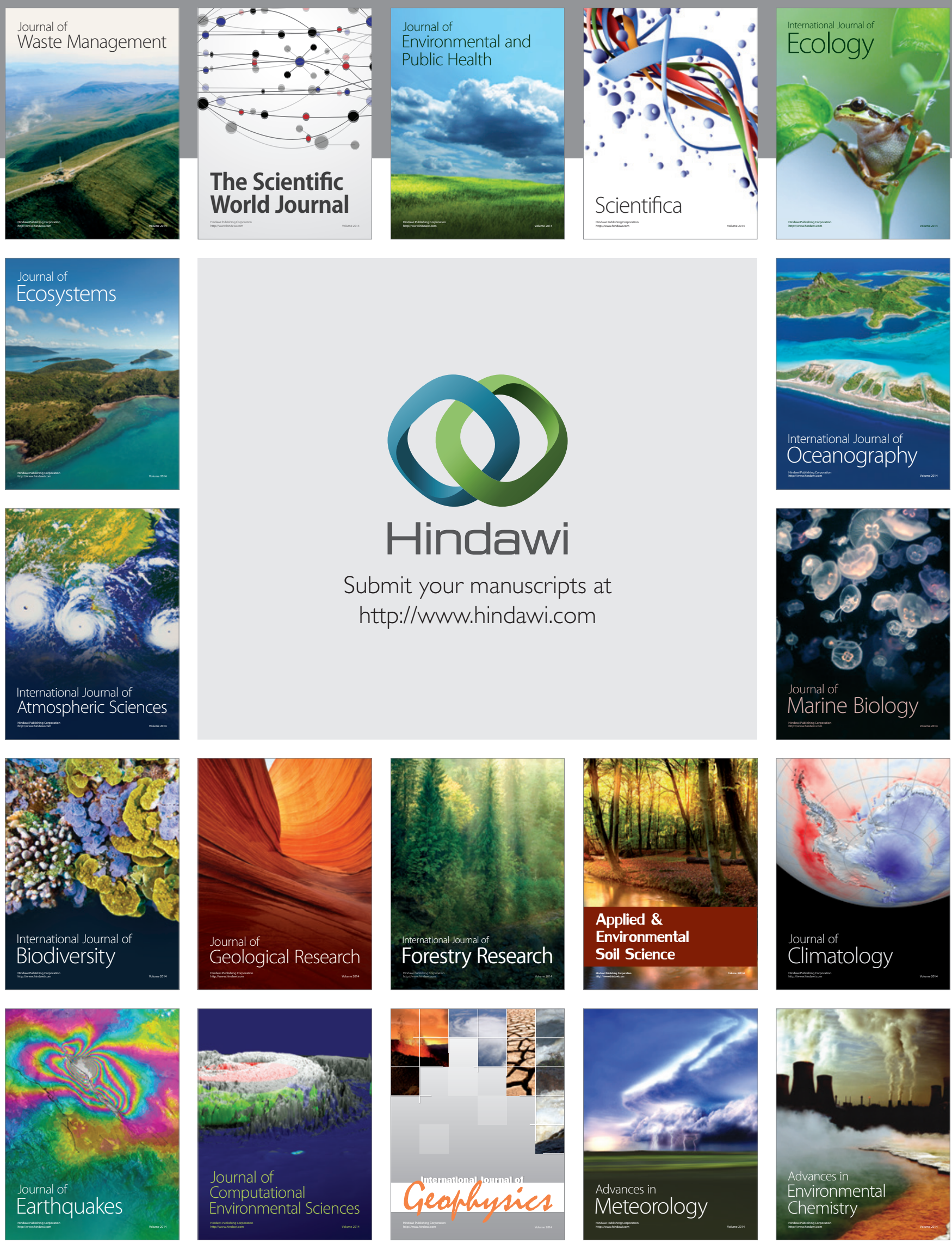